\title{
ANALISIS PENDPATAN PAJAK, PENDAPATAN RETRIBUSI, DAN PAD LAIN YANG SAH TERHADAP BELANJA MODAL KOTA MANADO 2005-2015
}

\author{
Royke Reynald Anter, Debby Ch. Rotinsulu, George M.V Kawung \\ Fakultas Ekonomi dan Bisnis, Magister Ilmu Ekonomi \\ Universitas Sam Ratulangi, Manado
}

\begin{abstract}
ABSTRAK
Pembangunan merupakan sebuah proses menuju kea rah yang lebih baik. Pembangunan daerah terlebih di Indonesia khususnya Kota Manado masih amat bergantung pada intervensi pemerintah melalui alokasi belanja yang dimiliki. Dalam penelitian ini bertujuan untuk melihat bagaimana pengaruh pendapatan yang di terima pemerintah daerah dalam bentuk Pendapatan Asli Daerah (PAD) yang terbagi dalam pendapatan Pajak, Retribusi, dan PAD lain yang sah, terhadap alokasi belanja modal pemerintah Kota Manado. Sepanjang 2005 hingga 2015. Di mana didapatkan hasil bahwa ketiga variabel independent kurang memberi pengaruh pada alokasi belanja modal
\end{abstract}

Kata Kunci : Pajak, Retribusi, Belanja Modal, PAD.

\begin{abstract}
Development is a process leading towards the better. Regional development especially in Indonesia, especially the city of Manado is still highly dependent on government intervention through budget allocations have. In this study aims to see how they affect the income received in the form of local government revenue (PAD) which is divided into income taxes, levies, and other legitimate PAD, the allocation of capital expenditures Manado city government. Throughout 2005 to 2015. Where is obtained that the three independent variables less influence on the allocation of capital expenditure
\end{abstract}

Keyword : taxes, Levies, State Income, Capital Expenditure

\section{Latar Belakang}

\section{PENDAHULUAN}

Desentralisasi dari pusat ke daerah merupakan sebuah tonggak utama dalam menjalankan semangat otonomi yang kian menggema di Tanah Air. Otonomi yang dimaksudkan adalah sebuah kepercayaan untuk mengelola wilayahnya masing-masing berlandaskan paham daerah yang paling mengena dan dirasa sesuai kemudian diterapkan dalam sebuah kebijakan daerah. Dengan konsep ini tentu diharapkan agar daerah yang berotonomi akan semakin dekat dengan masyarakat. Bukan hanya dalam hal kewenangan pemerintah daerah mendapat limpahan wewenang dari pemerintah pusat namun juga dalam hal keuangan pemerintah daerah juga mendapat kepercayaan untuk mengelola dan memanfatkan sebaikbaiknya dana yang ada untuk memajukan daerah serta mensejahterakan masyarakat yang ada dengan membuat kebijakan dan pengalokasian yang tepat sesuai dengan potensi-potensi perekonomian serta sector-sektor ekonomi yang dimiliki. Dengan adanya otonomi, daerah yang memaksimalkan sector-sektor ekonomi yang dimiliki tentu akan menurunkan angka kemiskinan yang dimiliki serta menyeap tenaga kerja yang ada di daerah melalui pembangunan yang ada, yang tentu dengan sendirinya akan meningkatkan kesejahteraan masyarakat.

Berdasarkan Undang-Undang No 33 Tahun 2004 tentang perimbangan keuangan antara pemerintah pusat dan daerah telah digulirkan pada 1 Januari 2001, menjadi acuan bagi pemerintah daerah untuk memiliki kemampuan lebih dalam hal kewenangan dari sentralisasi ke pusat menjadi desentralisasi ke daerah. Namun sayang hal ini kurang berimbas ke desentralisasi kemandirian antara pusat dan daerah meskipun pemberian otonomi bagi daerah saat ini sudah luas dan nyata. Hal ini tentu mengindikasikan 
bahwa kemampuan daerah untuk dapat mengatur perekonomian serta potensi yang dimilikinya masih sangat terbatas karena factor ketergantungan kepada pemerintah pusat yang masih amat besar, sehingga banyak kebijakan dari pemerintah pusat dalam pengelolaan potensi sumber keuangan harus diikuti oleh pemerintah daerah, dan sumber-sumber keuangan yang potensial masih tetap dikuasai oleh pemerintah pusat (Yani, 2002 : 3). Pengalihan pembiayaan dari pusat ke daerah atau yang lebih dikenal sebagai desentralisasi fiscal, dapat pula diartikan sebagai suatu proses distribusi anggaran dari pemerintah yang lebih tinggi kepada pemerintah yang lebih rendah untuk kemudian dikelola guna mendukung fungsi atau tugas pemerintahan dan pelayanan public sesuai dengan banyaknya wewenang bidang pemerintahan yang diberikan atau dilimpahkan oleh pemerintah pusat (Saragih 2003:82).

Dalam hubungannya, antara pemerintah pusat dan daerah menyangkut desentralisasi fiscal, dana perimbangan merupakan salah satu komponen utama yang mempengaruhi tingkat kemampuan daerah tersebut dalam mecukupi kebutuhan anggaran belanjanya di setiap periode. Perimbangan keuangan merupakan salah satu bentuk hubungan antara pemerintah pusat dan daerah dari sekian banyak hubungan yang dimilikinya, hubungan ini sendiri bersifat (intergovernmental fiscal relation system), sebagai salah satu bentuk kerjasama dalam pendelegasian wewenang pemerintah.

Dalam mengelola Anggaran Pendapatan dan Belanja Daerah (APBD) pemerintah yang sudah mendapatkan alokasi anggaran melalui dana transfer dari pemerintah pusat maupun dari sumber-sumber PAD kemudian membagi anggaran-anggaran tersebut menjadi belanja yang terbagi dalam belanja langsung atau belanja pembangunan dan belanja tidak langsung. Pengalokasian belanja ini ke sectorsektor ekonomi potensial yang kemudian akan menjadi salah satu item yang menggenjot pertumbuhan yang ada di daerah.

Sulawesi Utara sebuah wilayah yang berada di Indonesia bagian timur dan Utara pulau Sulawesi merupakan sebuah daerah yang mempunyai begitu banyak potensi. Mulai dari posisinya yang strategis di bibir samudera pasifik hingga produk serta kekayaan alam yang dimiliki. Saat ini Sulawesi Utara sendiri menjadi salah satu daerah yang tengah mendapat sorotan dari masyarakat terlebih dari sektor ekonomi, mengapa tidak, perputaran ekonomi yang terjadi dengan cepat di Sulawesi Utara menjadi salah satu pemicu perhatian tersebut. Pemerintah daerah tidak henti memacu kinerja guna meningkatkan kemampuan daerah, berbagai ide dan inovasi pun terus mencuat dari daerah yang juga dikenal sebagai bumi nyiur melambai. Letak geografisnya yang tepat berada di bibir samudera pasifik menjadikannya sebagai salah satu daerah yang menjadi incaran para pebisnis untuk menjadi tempat pertemuan dan melakukan perdagangan, bukan hanya di Indonesia namun juga perdagangan internasional.

Sebuah pembangunanan ekonomi adalah proses dimana pemerintah masyarakat serta pihak terkait mengelola dan memanfaatkan sumber daya yang secara maksimal serta membentuk lapangan kerja baru guna memaksimalkan potensi pertumbuhan ekonomi di dalam wilayah tersebut. Dewasa ini di berbagai daerah masih belum bisa menggelola dengan maksimal sektor-sektor perekonomian yang dimiliki dan masih tingginya tingkat ketergantungan terhadap dana dari pemerintah pusat.

Pendapatan Asli Daerah (PAD) yang masih tergolong rendah membuat pemerintah daerah belum bisa meningkatkan kemandiriannya yang berimbas pada pembangunan yang dilakukan di daerah yang bersangkutan sehingga masih tingginya tingkat kemiskinan yang dimiliki di daerah, karena kurangnya kesempatan kerja dan sedikit investor yang ingin menanamkan modalnya di sebuah daerah yang belum bisa menyediakan sarana dan prasarana investasi yang memadai. Akibatnya pemerintah pusat harus rela menanggung beban pengeluaran sebuah daerah dengan kucuran Dana Transfer untuk menggenjot Anggaran Pendapatan dan Belanja Daerah (APBD).

Saat ini guna menunjang pembangunan di daerah tentu dibutuhkan sumber-sumber pendapatan yang tidak sedikit antara lain dari Pendapatan Asli Daerah (PAD), serta Dana Transfer dari Pemerintah Pusat. Dalam era otonomi daerah seperti saat ini tentu proses pendelegasian wewenang yang diberikan pemerintah pusat dibarengi dengan tugas dan tanggung jawab yang besar untuk bisa lebih memaksimalkan potensipotensi yang dimiliki oleh daerah untuk dapat berkembang ke arah yang lebih baik.

Pengalihan pembiayaan dari pusat ke daerah atau yang lebih dikenal sebagai desentralisasi fiscal, dapat pula diartikan sebagai suatu proses distribusi anggaran dari pemerintah yang lebih tinggi kepada pemerintah yang lebih rendah untuk kemudian dikelola guna mendukung fungsi atau tugas pemerintahan 
dan pelayanan public sesuai dengan banyaknya wewenang bidang pemerintahan yang diberikan atau dilimpahkan oleh pemerintah pusat (Saragih $2003: 82$ ).

Dalam hubungannya, antara pemerintah pusat dan daerah menyangkut desentralisasi fiscal, dana perimbangan merupakan salah satu komponen utama yang mempengaruhi tingkat kemampuan daerah tersebut dalam mecukupi kebutuhan anggaran belanjanya di setiap periode. Perimbangan keuangan merupakan salah satu bentuk hubungan antara pemerintah pusat dan daerah dari sekian banyak hubungan yang dimilikinya, hubungan ini sendiri bersifat (intergovernmental fiscal relation system), sebagai salah satu bentuk kerjasama dalam pendelegasian wewenang pemerintah.

\section{Rumusan Masalah}

Tujuan utama dari pelaksanaan Otonomi adalah untuk membagi tanggung antara pemerintah pusat dan daerah yang bersangkutan, agar jalannya pemerintahan serta pelayanan masyarakat yang lebih terfokus karena pemerintah di daerah tentu lebih mengetahui permasalahan serta kebutuhan di daerah yang bersangkutan. Selain itu kemampuan sebuah daerah untuk mengelola serta memanfaatkan anggaran rumah tangganya sendiri sehingga bisa mencapai tahap yang maksimal dan dengan tujuan mensejahterakan masyarakat di daerah.

Hal ini tentu menarik untuk diteliti untuk melihat seberapa besar kontribusi pendapatan asli daerah (PAD) terhadap sektor pembiayaan pembangunannya.

Berdasarkan latar belakang yang ada maka rumusan masalah yang akan dibahas adalah : Bagaimana Pendapatan Pajak, Pendapatan Retribusi serta Pendapatan Asli Daerah Lain Yang Sah Berpengaruh Terhadap Belanja Modal di Kota Manado pada periode (2005 -2015)?

\section{Tujuan Penelitian}

Tujuan penelitian ini adalah

1. Bagaimana pengaruh Belanja Pendapatan Pajak terhadap Belanja Modal ?

2. Bagaimana pengaruh Belanja Pendapatan Retribusi terhadap Belanja Modal ?

3. Bagaimana pengaruh Belanja PAD Lain yang Sah terhadap Belanja Modal ?

\section{Manfaat Penelitian}

- Sebagai bahan masukan bagi pemerintah Kota Manado untuk mengetahui perkembangan perekonomiannya, terlebih dari sektor Pendapatan Asli Daerah serta belanja pembangunannya.

- Untuk digunakan pihak yang berkepentingan untuk menganalisa masalah - masalah yang berhubungan dengan Pengelolaan fiskal Kota Manado.

\section{Pendapatan Asli Daerah}

\section{TINJAUAN PUSTAKA}

Pendapatan asli daerah yang selanjutnya disebut PAD yaitu bersumber dari Pendapatan hasil Pajak, hasil Retribusi Daerah, hasil-hasil pengelolaan kekayaan daerah yang dipisahkan; dan lain-lain PAD yang sah. Pajak daerah dan retribusi daerah ditetapkan. dengan Undang-Undang yang pelaksanaannya di daerah diatur lebih lanjut dengan Perda. Pemerintahan daerah dilarang melakukan pungutan atau dengan sebutan lain di luar yang telah ditetapkan Undang-Undang.

Augustyas, (2013) mengatakan Pendapatan Asli Daerah merupakan sumber pendapatan daerah yang berasal dari kegiatan ekonomi daerah itu sendiri. Pendapatan Asli Daerah (PAD) merupakan salah satu pilar kemandirian suatu daerah. Menurut Undang-Undang Nomor 33 Tahun 2004 tentang perimbangan keuangan antara pemerintah pusat dan daerah, sumber PAD terdiri dari pajak daerah, retribusi daerah, hasil pengelolaan kekayaan daerah, dan lain-lain pendapatan daerah yang sah. Pengembangan potensi akan menciptakan pendapatan asli daerah bagi yang berguna untuk melaksanakan tujuan pembangunan. Pengelolaan pendapatan asli daerah yang efektif dan efisien perlu dilaksanakan dengan mempertimbangkan kondisi ekonomi daerah maupun perekonomian nasional. Kontribusi yang dicapai dari pendapatan asli daerah dapat terlihat dari seberapa besar pendapatan tersebut disalurkan untuk membangun daerah agar lebih berkembang dan mampu meningkatkan kesejahteraan masyarakat. 


\section{Lain-lain Pendapatan Daerah Yang Sah}

Lain-lain pendapatan daerah yang sah sebagaimana yang dimaksud dalam Undang-Undang Republik Indonesia No 32 Tahun 2004 merupakan seluruh pendapatan daerah selain PAD dan Dana Perimbangan, yang meliputi hibah, dana darurat, dan lain-lain pendapatan yang ditetapkan Pemerintah. Dana hibah merupakan bantuan berupa uang, barang, dan/ atau jasa yang diberikan dari pemerintah, masyarakat dan badan usaha dalam Negeri atau luar Negeri. Dana Darurat merupakan bantuan dari Pemerintah dari APBN kepada Pemerintah Daerah untuk mendanai keperluan mendesak yang diakibatkan peristiwa tertentu yang tidak dapat ditanggulangi oleh APBD.

Jenis lain-lain pendapatan asli daerah yang sah disediakan untuk menganggarkan penerimaan daerah yang tidak termasuk dalam jenis pajak daerah, retribusi daerah, dan hasil pengelolaan kekayaan daerah yang dipisahkan dirinci menurut obyek pendapatan yang antara lain:

- hasil penjualan kekayaan daerah yang tidak dipisahkan secara tunai atau angsuran/cicilan;

- jasa giro;

- pendapatan bunga

- $\quad$ penerimaan atas tuntutan ganti kerugian daerah;

- penerimaan komisi, potongan ataupun bentuk lain sebagai akibat dari penjualan dan/atau pengadaan barang dan/atau jasa oleh daerah

- penerimaan keuntungan dari selisih nilai tukar rupiah terhadap mata uang asing;

- pendapatan denda atas keterlambatan pelaksanaan pekerjaan

- pendapatan denda pajak;

- pendapatan denda retribusi

- pendapatan hasil eksekusi atas jaminan

- pendapatan dari pengembalian

- fasilitas sosial dan fasilitas umum

- pendapatan dari penyelenggaraan pendidikan dan pelatihan

- pendapatan dari Badan Layanan Umum Daerah (BLUD).

\section{Belanja Modal}

Menurut Peraturan Menteri Dalam Negeri Nomor 13 Tahun 2006 tentang Pedoman Pengelolaan Keuangan Daerah Pasal 53, belanja modal adalah anggaran pengeluaran APBD yang digunakan untuk pengeluaran yang dilakukan dalam rangka pembelian/ pengadaan atau pembangunan aset tetap berwujud yang mempunyai nilai manfaat lebih dari 12 (dua belas) bulan untuk digunakan dalam kegiatan pemerintahan, seperti dalam bentuk tanah, peralatan dan mesin, gedung dan bangunan, jalan, irigasi dan jaringan, dan asset tetap lainnya. Belanja modal menurut Peraturan Menteri Dalam Negeri Nomor 59 Tahun 2007 tentang Perubahan Atas Peraturan Menteri Dalam Negeri Nomor 13 Tahun 2006 tentang Pedoman Pengelolaan Keuangan Daerah Ketentuan Pasal 52, adalah belanja barang atau jasa yang dianggarkan pada pengeluaran APBD yang digunakan untuk menganggarkan pengadaan barang dan jasa yang nilai manfaatnya lebih dari 12 (dua belas) bulan dalam melaksanakan program dan kegiatan pemerintah daerah. Nilai asset tetap berwujud yang dianggarkan dalam belanja modal sebesar harga beli/ bangun aset ditambah seluruh belanja yang terkait dengan pengadaan/ pembangunan aset sampai aset tersebut siap digunakan (Rudy Badrudin, 2012: 61). Menurut Abdul Halim (2008: 4-5) dalam Rudy Badrudin (2012), belanja modal adalah investasi yang berupa pengadaan atau pembelian aset yang bermanfaat lebih dari 12 (dua belas) bulan dan aset tersebut digunakan dalam kegiatan pemerintahan yang bermanfaat secara ekonomis, sosial, dan manfaat lainnya sehingga dapat meningkatkan kemampuan pemerintah dalam melayani masyarakat. Dengan demikian, belanja modal bermanfaat untuk meningkatkan kesejahteraan masyarakat. Aset tetap merupakan prasyarat utama dalam memberikan pelayanan publik oleh pemerintah daerah. Untuk menambah asset tetap, pemerintah daerah mengalokasikan dalam bentuk belanja modal dalam APBD. Alokasi belanja modal ini didasarkan pada kebutuhan daerah akan sarana dan prasarana, baik untuk kelancaran pelaksanaan tugas pemerintahan 
maupun untuk fasilitas publik. Biasanya setiap tahun diadakan pengadaan aset tetap oleh pemerintah, sesuai dengan prioritas anggaran dan pelayanan publik yang memberikan dampak jangka panjang secara finansial. Menurut Abdul Halim (2007: 113-114) dalam Rudy Badrudin (2012), belanja modal dapat dikategorikan dalam lima kategori utama yaitu:

a. Belanja Modal Tanah

Belanja modal tanah adalah pengeluaran atau biaya yang digunakan untuk pengadaan atau pembelian atau pembebasan penyelesaian, baik nama dan sewa tanah, pengosongan, pengurugan, peralatan, pematangan tanah, pembuatan sertifikat, dan pengeluaran lainnya yang sehubungan dengan perolehan hak atas tanah sampai tanah yang dimaksud dalam kondisi siap pakai.

b. Belanja Modal Peralatan dan Mesin

Belanja modal peralatan dan mesin adalah pengeluaran atau biaya yang digunakan untuk pengadaan atau penambahan atau penggantian dan peningkatan kapasitas peralatan dan mesin serta inventaris kantor yang memberi manfaat lebih dari dua belas bulan dan sampai peralatan dan mesin dimaksud dalam kondisi siap pakai.

c. Belanja Modal Gedung dan Bangunan

Belanja modal gedung dan bangunan adalah pengeluaran atau biaya yang digunakan untuk pengadaan atau penambahan atau penggantian dan termasuk pengeluaran untuk perencanaan, pengawasan, dan pengelolaan pembangunan gedung dan bangunan yang menambah kapasitas sampai gedung dan bangunan yang dimaksud dalam kondisi siap pakai.

d. Belanja Modal Jalan, Irigasi, dan Jaringan

Belanja modal jalan, irigasi, dan jaringan adalah pengeluaran atau biaya yang digunakan untuk pengadaan atau penambahan atau penggantian dan peningkatan pembangunan atau pembuatan serta perawatan, dan pengelolaan jalan, irigasi, dan jaringan yang menambah kapasitas sampai jalan, irigasi, dan jaringan yang dimaksud dalam kondisi siap pakai.

e. Belanja Modal Fisik Lainnya

Belanja modal fisik lainnya adalah pengeluaran atau biaya yang digunakan untuk pengadaan atau penambahan atau penggantian atau peningkatan atau pembangunan atau pembuatan serta perawatan terhadap fisik lainnya yang tidak dapat dikategorikan ke dalam kriteria belanja modal tanah, peralatan dan mesin, gedung dan bangunan, jalan, irigasi, serta jaringan, termasuk juga dalam belanja ini adalah belanja modal kontrak sewa beli, pembelian barangbarang kesenian, barang purbakala dan barang untuk museum, hewan ternak dan tanaman, buku-buku, dan jurnal ilmiah.

\section{Kerangka Pemikiran}

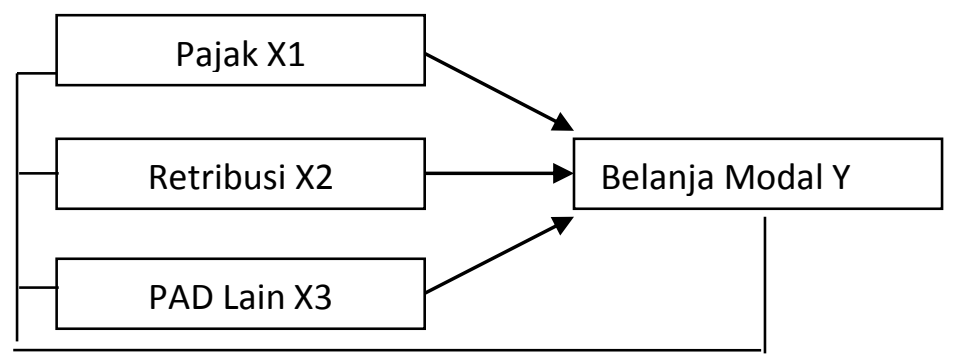

\section{Hipotesis}

1. Diduga bahwa pendapatan pajak memberi pengaruh pada alokasi belanja modal kota Bitung $\backslash$

2. Diduga bahwa pendapatan retribusi memberi pengaruh pada alokasi belanja modal kota Bitung

3. Diduga bahwa pendapatan PAD Lain yang sah memberi pengaruh pada alokasi belanja modal kota Bitung 


\section{Jenis dan Sumber Data}

\section{METODE PENELITIAN}

Data yang digunakan dalam penelitian ini adalah data sekunder atau mengambil data yang sudah tersedia di instansi tertentu yang sesuai dengan jenis penelitian dan dalam penelitian ini mengambil data dari Badan Perencanaan dan Pembangunan Kota Manado (Bappeda) dan dari badan pusat Statistik (BPS) Provinsi Sulawesi Utara.

\section{Metode Pengumpulan Data}

Metode pengambilan data sekunder, data dikumpulkan dengan metode dokumentasi. Ini dilakukan dengan mengumpulkan, mencatat dan menghitung data-data yang berhubungan dengan penelitian. Penelitian ini mengambil data dari APBD Kota Manado tahun 2007 sampai 2014.

\section{Metode Analisis}

Penelitian ini dengan menggunakan pendekatan kuantitatif. Secara umum, pendekatan kuantitatif lebih fokus pada tujuan untuk generalisasi, dengan melakukan pengujian statistik dan steril dari pengaruh subjektif peneliti (Sekaran, 1992). Alat analisis yang digunakan dalam penelitian ini adalah analisis regresi linier berganda. Analisis regresi berganda adalah analisis mengenai beberapa variabel independen dengan satu variabel dependen.

Secara umum, analisis regresi adalah analisis mengenai variabel independen dengan variabel dependen yang bertujuan untuk mengestimasi nilai rata-rata variabel dependen berdasarkan nilai variabel independen yang diketahui (Gujarati, 2003). Teknik yang digunakan untuk mencari nilai persamaan regresi yaitu dengan analisis Least Squares (kuadrat terkecil) dengan meminimalkan jumlah dari kuadrat kesalahan.

Dalam analisis regresi selain mengukur seberapa besar hubungan antara variabel independen dengan variabel dependen, juga menunjukkan bagaimana hubungan antara variabel independen dengan dependen, sehingga dapat membedakan variabel independen dengan variabel dependen tersebut (Ghozali, 2006). Dimana dalam penelitian ini, tiga komponen dari pendapatan daerah yaitu pajak daerah, dana retribusi dan PAD lain yang sah sebagai variabel independen, akan dianalisis pengaruhnya terhadap alokasi belanja daerah yang diukur belanja langsung sebagai variabel dependen.

\section{Hasil Penelitian}

\section{HASIL DAN PEMBAHASAN}

Dari hasil penelitian tentang pengaruh pajak daerah,retribusi daerah dan PAD lain yang sah terhadap belanja langsung ialah sebagai berikut

\section{Pengujian Asumsi klasik Multikolerasi}

Tabel 1 multikorelasi

\begin{tabular}{|l|l|l|}
\hline Correlations & \multicolumn{2}{|l|}{ Collinearity Statistics } \\
\hline Part & Tolerance & VIF \\
\hline & & \\
\hline 358 & .390 & 2,565 \\
\hline .134 & .478 & 2,091 \\
\hline-.004 & .594 & 1,683 \\
\hline
\end{tabular}

a. Dependent Variable: Belanja Modal

Sumber data : Pengolahan Data 2016

Dilihat dari tabel 1 Coefficients nilai VIF pada Output menunjukkan keberadaan multikolinearitas.

Bila VIF < 10,00 maka tidak terjadi gejala Multikolerasi 
Bila VIF > 10,00 maka terjadi gejala Multikolerasi

Dengan Hasil :

Nilai Tolerance : X1 PAJAK DAERAH $\quad=0,390$

$:$ X2 RETRIBUSI DAERAH $=0,478$

$:$ X3 PAD LAIN $=0,594$

Nilai VIF $\quad:$ X1 PAJAK DAERAH $\quad=2,565$

$:$ X2 RETRIBUSI DAERAH $\quad=2.091$

$:$ X3 PAD LAIN $=1,594$

\section{Diagram Uji Heterokoledasitas}

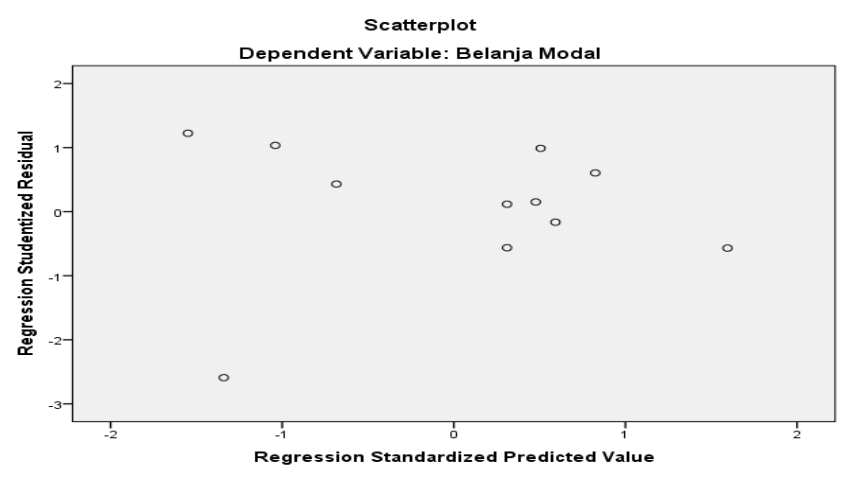

Gambar 1 Kurva Uji Heterokedastisitas hasil Model Penelitian

Dari diagram diatas tersebut terlihat bahwa penyebaran residual tidak teratur. Hal tersebut terlihat pada plot yang terpancar dan tidak membentuk pola tertentu. Dengan hasil demikian, kesimpulan yang biasa diambil adalah bahwa tidak terjadi gejala homokedastisitas atau persamaan regresi memenuhi asumsi heterokedatisitas.

\section{Uji Autokorelasi}

Tabel 2 Uji Aotukorelasi

\begin{tabular}{|c|c|c|c|c|c|c|}
\hline \multirow[b]{2}{*}{ Model } & \multicolumn{5}{|c|}{ Change Statistics } & \multirow[b]{2}{*}{$\begin{array}{l}\text { Durbin- } \\
\text { Watson }\end{array}$} \\
\hline & $\begin{array}{l}\text { R Square } \\
\text { Change }\end{array}$ & F Change & df1 & df2 & \begin{tabular}{|l} 
Sig. F \\
Change
\end{tabular} & \\
\hline 1 & .520 & 2.524 & 3 & $7^{\mathrm{a}}$ & .141 & 1.580 \\
\hline
\end{tabular}

a. Predictors: (Constant), PAD LAIN, RETRIBUSI, PAJAK Model Summary (b)

b. Dependent Variable: BELANJA MODAL

Sumber data : Pengolahan Data 2016

Pada analisis regresi telihat bahwa nilai DW 2,606 dan nilai DL 0.5253 , dan DU 2.0163 .DL < DW < DU yakni 0.5253 DL, 1,580 DW, 2,0163 DU. DW berada pada antara DL dan DU dan berada pada titik keragu-raguan. Maka dapat disimpulkan bahwa terdapat gejala autokorelasi yang lemah. 


\title{
Pengaruh secara langsung Variabel Independen Exogenus Pajak Daerah, Retribusi Daerah dan PAD Lain terhadap Variabel dependen Endogenus Belanja Modal
}

Model Summary ${ }^{\mathrm{b}}$

\author{
Tabel 3 Tabel R-Square
}

\begin{tabular}{|c|c|c|c|c|c|c|c|}
\hline \multirow[t]{2}{*}{ Model } & \multirow[t]{2}{*}{$\mathrm{R}$} & \multirow[t]{2}{*}{ R Square } & \multirow{2}{*}{$\begin{array}{l}\text { Adjusted R } \\
\text { Square }\end{array}$} & \multicolumn{4}{|c|}{ Std. Error of the Change Statistics } \\
\hline & & & & Estimate & $\begin{array}{l}\text { R Square } \\
\text { Change }\end{array}$ & F Change & df1 \\
\hline 1 & $.721^{\mathrm{a}}$ & .520 & .314 & .29466 & .520 & 2.524 & 3 \\
\hline
\end{tabular}

a. Predictors: (Constant), Pajak, Retribusi, PAD lain

b. Dependent Variable: Belanja Modal

Dalam melihat pengaruh Variabel Independen Exogenus Pajak Derah, Retribusi Daerah dan PAD Lain secara gabungan terhadap variabel Dependen Endogenus Belanja Modal dapat dilihat pada Tabel 3 Model Summary diatas, pada nilai R square. Besarnya R square (R2) pada tabel dibawah ini adalah 0,520. Angka tersebut mempumpunyai makna Besarnya pengaruh Variabel independen exogenous Pajak Daerah, Retribusi Daerah Dan Pad Lain terhadap variabel dependen endogenus Belanja Modal secara gabungan. Dalam menghitung Koefisien Determinasi (KD) dapat diketahui dengan rumus :

$$
\begin{aligned}
& \mathrm{KD}=\mathrm{R} 2 \times 100 \% \\
& \mathrm{KD}=0,520 \times 100 \% \\
& \mathrm{KD}=52,0 \%
\end{aligned}
$$

Besarnya pengaruh Variabel Independen Exogenous Pajak Daerah, Retribusi Daerah Dan PAD Lain terhadap Variabel Dependen Endogenus Belanja Langsung secara gabungan adalah 94,9\%.Dan pengaruh diluar model dapat di hitung dengan :

$$
\begin{aligned}
& \mathrm{e}=1-\mathrm{R}^{2} \\
& \mathrm{e}=1-0,480 \\
& \mathrm{e}=0,480 \times 100 \% \\
& \mathrm{e}=48,0 \%
\end{aligned}
$$

Yang berarti $48 \%$ adalah besarnya faktor lain yang mempengaruhi diluar model yang di teliti. Artinya besarnya pengaruh variabel independen ekxogenus Pajak Daerah, Retribusi Daerah Dan PAD Lain terhadap variabel dependen endogenus Belanja Langsung adalah sebesar $52 \%$, sedangkan pengaruh sebesar $48 \%$ disebabkan oleh variabel di luar model yang di teliti.

Coefficients $^{\mathrm{a}}$

Tabel 4 Uji Beta

\begin{tabular}{|ll|l|l|l|l|l|}
\hline \multicolumn{2}{|l|}{ Model } & \multicolumn{2}{|l|}{ Unstandardized Coefficients } & $\begin{array}{l}\text { Standardized } \\
\text { Coefficients }\end{array}$ & & \multirow{2}{*}{ Sig. } \\
\cline { 3 - 5 } & & B & Std. Error & Beta & & \\
\hline \multirow{4}{*}{1} & (Constant) & 2.547 & 4.965 & & .513 & .624 \\
& PAD lain & .525 & .385 & .573 & 1.365 & .215 \\
& Retribusi & .332 & .652 & .193 & .510 & .626 \\
& Pajak & -.005 & .326 & -.005 & -.015 & .989 \\
\hline
\end{tabular}

a. Predictors: (Constant), Pajak, Retribusi, PAD lain

b. Dependent Variable: Belanja Modal 


\section{Pengaruh Variabel Independen Exogenous Pengeluaran Pajak Daerah dan Variabel Dependen Endogenus Belanja Modal}

Untuk melihat apakah ada Pengaruh Linier Variabel Independen Exogenus Pengeluaran Pajak Daerah terhadap Variabel Dependen Endogenus Belanja Langsung. Dapat dilihat pada tabel Coefficients(a) Menentukan besarnya taraf Signifikan sebesar 0,05 dan Degree of Freedom DF $=\mathrm{n}-$ $(\mathrm{K}+1)$ atau $\mathrm{DF}=10-(3+1)=6$. Dari ketentuan tersebut diperoleh $\mathrm{t}$ tabel sebesar 1,943 (untuk uji dua arah) Dalam perhitungan SPSS yang tertera pada tabel Coefficients di atas dimana tabel $t$ adalah untuk menunjukan bahwa adanya Pengaruh linier antara Variabel Independen Exogenus pajak daerah terhadap Variabel Dependen Endogenus belanja langsung ialah -0,015.

Pengujian Hipotesis t kriterianya sebagai berikut :

1. Jika t hitung $>\mathrm{t}$ tabel, maka $\mathrm{HO}$ ditolak, dan $\mathrm{H} 1$ diterima

2. Jika t hitung < t tabel, maka H0 diterima, dan H1 ditolak

Dimana dalam melihat pengaruh signifikan atau tidak Kriterianya adalah sebagai berikut :

1. Jika Signifikan $<0,05$ maka berpengaruh signifikan

2. Jika Signifikan $>0,05$ maka tidak ada pengaruh signifikan

Hasil dari perhitungan dengan SPSS menunjukan angka t hitung sebesar $-0,015<\mathrm{t}$ tabel sebesar 1,943. Dengan demikian keputusanya ialah H0 ditolak dan H1 diterima. Artinya ada pengaruh linier antara Variabel Independen Exogenus pajak daerah terhadap Variabel Dependen Endogenus belanja Modal. Maka Variabel Independen Exogenus pajak daerah berpengaruh terhadap Variabel Dependen Endogenus belanja Modal. Besarnya pengaruh Variabel Independen Exogenus pajak daerah terhadap Variabel Dependen Endogenus belanja langsung diketahui dari nilai Koefisien Beta (dalam kolom Standardized Coefficients Beta) ialah -0,005 tidak Signifikan karena nilai signifikansi / probabilitas hasil yang tertera pada kolom Sig 0,989>0,05.

\section{Pengaruh Variabel Independen Exogenous Retribusi Daerah dan Variabel Dependen Endogenus Belanja Modal.}

Untuk melihat apakah ada Pengaruh Linier Variabel Independen Exogenus Pengeluaran retribusi Daerah terhadap Variabel Dependen Endogenus Belanja Langsung. Dapat dilihat pada tabel Coefficients(a) Menentukan besarnya taraf Signifikan sebesar 0,05 dan Degree of Freedom DF $=n(K+1)$ atau $\mathrm{DF}=10-(3+1)=6$. Dari ketentuan tersebut diperoleh $\mathrm{t}$ tabel sebesar 1,943 (untuk uji dua arah) Dalam perhitungan SPSS yang tertera pada tabel Coefficients di atas dimana tabel $\mathrm{t}$ adalah untuk menunjukan bahwa adanya Pengaruh linier antara Variabel Independen Exogenus retribusi daerah terhadap Variabel Dependen Endogenus belanja Modal ialah 0,510. Pengujian Hipotesis t kriterianya sebagai berikut :

1. Jika t hitung $>\mathrm{t}$ tabel, maka $\mathrm{H} 0$ ditolak, dan $\mathrm{H} 1$ diterima

2. Jika t hitung < t tabel, maka H0 diterima, dan H1 ditolak

Dimana dalam melihat pengaruh signifikan atau tidak Kriterianya adalah sebagai berikut :

1. Jika Signifikan $<0,05$ maka berpengaruh signifikan

2. Jika Signifikan $>0,05$ maka tidak ada pengaruh signifikan

Hasil dari perhitungan dengan SPSS menunjukan angka $t$ hitung sebesar 0,510 $>\mathrm{t}$ tabel sebesar 1,943 . Dengan demikian keputusanya ialah H0 diterima dan H1 ditolak. Artinya tidak ada pengaruh linier antara Variabel Independen Exogenus retribusi daerah terhadap Variabel Dependen Endogenus belanja modal. Maka Variabel Independen Exogenus Retribusi daerah tidak berpengaruh terhadap Variabel Dependen Endogenus belanja modal. Besarnya pengaruh Variabel Independen Exogenus retribusi daerah terhadap Variabel Dependen Endogenus belanja langsung diketahui dari nilai Koefisien Beta (dalam kolom Standardized Coefficients Beta) ialah 0,193 tidak Signifikan karena nilai signifikansi/ probabilitas hasil yang tertera pada kolom Sig 0,625. 


\section{Pengaruh Variabel Independen Exogenous PAD Lain dan Variabel Dependen Endogenus Belanja Modal.}

Untuk melihat apakah ada Pengaruh Linier Variabel Independen Exogenus Pengeluaran PAD Lain terhadap Variabel Dependen Endogenus Belanja Langsung. Dapat dilihat pada tabel Coefficients(a) Menentukan besarnya taraf Signifikan sebesar 0,05 dan Degree of Freedom DF $=n-(K+1)$ atau DF $=10$ $-(3+1)=6$. Dari ketentuan tersebut diperoleh $\mathrm{t}$ tabel sebesar 1,943 (untuk uji dua arah) Dalam perhitungan SPSS yang tertera pada tabel Coefficients di atas dimana tabel $t$ adalah untuk menunjukan bahwa adanya Pengaruh linier antara Variabel Independen Exogenus PAD Lain terhadap Variabel Dependen Endogenus belanja modal ialah 1.365. Menghitung besarnya angka t tabel / nilai kritis dengan ketentuan sebagai berikut :

Pengujian Hipotesis t kriterianya sebagai berikut :

1. Jika thitung > t tabel, maka H0 ditolak, dan $\mathrm{H} 1$ diterima

2. Jika t hitung < t tabel, maka H0 diterima, dan H1 ditolak

Dimana dalam melihat pengaruh signifikan atau tidak Kriterianya adalah sebagai berikut :

1. Jika Signifikan $<0,05$ maka berpengaruh signifikan

2. Jika Signifikan $>0,05$ maka tidak ada pengaruh signifikan

Hasil dari perhitungan dengan SPSS menunjukan angka t hitung sebesar $-1.365<\mathrm{t}$ tabel sebesar 1,943. Dengan demikian keputusanya ialah H0 diterima dan H1 ditolak. Artinya tidak ada pengaruh linier antara Variabel Independen Exogenus PAD Lain terhadap Variabel Dependen Endogenus belanja langsung. Maka Variabel Independen Exogenus PAD Lain tidak berpengaruh terhadap Variabel Dependen Endogenus belanja modal. Besarnya pengaruh Variabel Independen Exogenus PAD Lain terhadap Variabel Dependen Endogenus belanja langsung diketahui dari nilai Koefisien Beta (dalam kolom Standardized Coefficients Beta) ialah 0,573 tidak Signifikan karena nilai signifikansi / probabilitas hasil yang tertera pada kolom Sig 0,215 > 0,05.

\section{Melihat Kelayakan Model Regresi}

Untuk mengetahui model regresi yang telah dibuat sudah benar adalah dengan menggunakan pengujian dengan dua cara, yaitu Pertama menggunakan nilai $F$ pada tabel keluaran ANOVA, dan Kedua dengan cara menggunakan nilai Probabilitas / nilai Sig pada tabel 4.6 keluaran ANOVA.

Tabel 5 Tabel Kelayakan Model Regresi ANOVA $^{\mathrm{a}}$

\begin{tabular}{|ll|l|l|l|l|l|}
\hline Model & & Sum of Squares & df & Mean Square & F & Sig. \\
\hline \multirow{2}{*}{$\begin{array}{l}1 \\
1\end{array}$} & Regression & 657 & 3 & .219 & 2.524 & $.141^{\mathrm{b}}$ \\
& Residual & .608 & 7 & .087 & & \\
& Total & 1.265 & 10 & & & \\
\hline
\end{tabular}

a. Predictors: (Constant), PAD Lain, Retribusi Daerah, Pajak Daerah

b. Dependent Variable: Belanja Modal

Sumber Data : Pengolahan Data 2016

Menghitung nilai F tabel dengan Ketentuan besar nilai taraf Signifikansi sebesar 0,05 dan Nilai Degree Of Freedom dengan ketentuan Numerator / Vektor 1: Jumlah Variabel -1 atau $4-1=3$, dan dumerator / Vektor 2 : jumlah kasus-jumlah variabel atau $10-4=6$. Dengan ketentuan terdebut diperoleh angka $\mathrm{F}$ tabel sebesar 4.76 .

Dengan kriteria pengambilan keputusan hasil pengujian hipotesis

Jika F hitung > F tabel, maka H0 ditolak, H1 diterima.

Jika F hitung < F tabel, maka H0 diterima dan H1 ditolak.

Hasil uji hipotesis adalah :

Hasil perhitungan dengan SPSS didapatkan angka F hitung sebesar $2.524<\mathrm{F}$ tabel sebesar 4,76. Dengan demikian $\mathrm{H} 0$ diterima, dan H1 ditolak. Artinya tidak ada hubungan linier antara Variabel Independen 
Eksogenus Pajak Daerah, Retribusi Daerah dan PAD lain dengan Variabel Dependen Endogenus belanja modal. Dengan nilai Sig 0,141 Kesimpulan adalah model regresi di atas sudah layak dan benar.

\section{Pembahasan}

Dari hasil penelitian yang di lakukan, Pajak Daerah, Retribusi Daerah dan PAD lain terhadap belanja modal jika dilihat dari uji multikorelasi tidak terjadi multikorelasi karena nilai VIF dari ketiga variabel tersebut lebih kecil dari 10,00. Untuk pengujian secara bersama-sama pengaruh antara variabel independen pajak daerah, retribusi daerah, dan PAD lain yang sah adalah sebesar sebesar $52 \%$. Hal ini dapat menjadi gambaran bahwa, pengaruh ketiga variable independen yang dipilih berpengaruh cukup besar terhadap perubahan yang terjadi pada alokasi belanja modal yang dilakukan pemerintah kota Manado. hal ini cukup wajar mengingat alokasi belanja modal yang dilakukan pemerintah untuk meningkatkan sumber-sumber PAD di tahun berikutnya berdasarkan ketentuan haruslah bersumber dari PAD daerah bersangkutan. Namun berdasarkan keadaan saat ini daerah otonomi belum mampu membiayai sendiri anggaran belanjanya dan masih harus bergantung pada alokasi dana transfer dari pemerintah pusat dalam bentuk dana alokasi umum (DAU). Hal ini tentu juga memberi pengaruh terhadap peningkatan alokasi belanja modal yang dilakukan oleh pemerintah.

Dalam beberapa tahun belakangan perkembangan kemnadirian serta peningkatan PAD kota Manado terus menunjukan tren yang positif, apalagi melihat perkembangan berbagai sumber-sumber pendapatan daerah yang terus menunjukan pertumbuhan yang berarti. Namun berdasarkan penelitian sumber-sumber pendapatan tersebut yang disatukan dalam PAD belum mampu sepenuhnya memenuhi kebutuhan akan belanja yang dilakukan pemerintah baik belanja untuk fasilitas publik maupun untuk belanja pengembangan sector ekonomi. Untuk itu perlu ada kebijakan yang lebih mengena dan berdampak langsung ke sector-sektor ekonomi tersebut agar membuka jalan untuk terus tumbuh dan berkembang sehingga pertumbuhan yang sudah baik terjadi dapat terus ditingkatkan dan pada akhirnya akan mampu membiayai keuangan daerah sendiri, yang ujungnya adalah untuk meningkatkan kesejahteraan masyarakat banyak.

\section{Kesimpulan}

Dari hasil penelitian yang dilakukan didapatkan hasil bahwa pajak, retribusi dan PAD lain yang sah secara sendiri-sendiri belum mampu memberi kntribusi yang maksimal dan signifikan terhadap belanja modal yang dilakukan pemerintah kota Manado, hal ini mengingat besaran pendapatan yang diterima dari masing-masing variable independen ini masih amat kecil dibandingkan dengan alokasi anggaran belanja modal yang dialokasikan oleh pemerintah, ini juga menjadi gambaran bahwa pemerintah kota Manado dalam hal ini masih mempunyai ketergantungan besar terhadap alokasi dana transfer atau dana perimbangan dari pemerintah pusat. Saat ini sendiri kota Manado tercatat sudah mampu sedikit demi sedikit memperbaiki tingkat kemandiriannya yang saat ini sudah mencapai angka 23 persen atau $256 \mathrm{M}$ dari total anggaran 1,3 T, meskipun kian menunjukan tren yang positif dan kian membaik dari tahun ke tahun namun dapat juga digambarkan dalam penelitian ini bahwa pendapatan asli daerah belum mampu menjadi tulang punggung maupun acuan kemampuan keuangan kota Manado.

\section{Saran}

Berdasarkan hasil penelitian pengaruh Pendapatan pajak, retribusi dan pad lain yang sah terhadap belanja langsung atau belanja pembangunan yang dilakukan oleh pemerintah penulis coba memberikan saran :

a. Mempertahankan kinerja pengelolaan yang sudah tertata dengan baik di pemerintah kota Manado, terlebih dalam pengelolaan sumber-sumber pendapatan asli daerah yang masih belum terkelola secara maksimal agar dapat memberikan kotribusi yang lebih maksimal terhadap belanja pembangunan.

b. Membuka sector-sektor ekonomi potensial yang dapat menjadi sumber-sumber pendapatan daerah agar dapat meningkatkan taraf kemandiriannya dan tidak terlalu bergantung pada kucuran dana dari pemerintah pusat dalam bentuk dana transfer, dan dengan adanya sumber- 
sumber ekonomi baru ini diharapkan belanja pembangunan yang dilakukan oleh pemerintah Kota Manado akan bisa berkembang lebih baik lagi dan tentunya menjadi salah satu sarana bagi pemerintah untuk mengurangi tingkat kemiskinan karena dengan adanya sumber perekonomian yang baru maka tentunya akan menyerap tenaga kerja yang belum bisa terserap sebelumnya karena kurangnya kesempatan kerja.

\section{Daftar Pustaka}

Bovee, Courthland L., dan William F. Arens, 1986, Comtemporary Advertising, Illionis: Irwan Homewood

Djojohadikusumo, Sumitro. 1994. Perkembangan Pemikiran Ekonomi : dasar teori ekonomi pertumbuhan dan ekonomi pembangunan. Edisi pertama, Jakarta : Pustaka LP3ES.

Kevin D. Hoover, Steven M Sheffrin, the American Economics review, vol 82, no.1 (Mar.

Kuncoro, Mudrajat, 2003, Metode Riset untuk Bisnis \& Ekonomi, Bagaimana Meneliti \& Menulis Tesis?, Erlangga, Jakarta

Kuncoro, Mudrajat, 2004, Otonomi dan Pembangunan Daerah, Erlangga, Jakarta

Lovelock, Christopher H., and Lauren K, Wright. 2005. Principles of Service Marketing Management. New Jeresey: Prentice-Hall, Inc

Mardiasmo, 2009, Perpajakan, Yogyakarta : Andi. Edisi Revisi.

Marihot Pahala Siahan, 2010, Pajak Daerah dan Retribusi Daerah, Edisi Revisi, Jakarta :

PT Raja Grafindo Persada

Mangkoesoebroto. 1993. Ekonomi Publik (Edisi 3). Yogyakarta : BPFE UGM

Marihot Pahala Siahan, 2010, Pajak Daerah dan Retribusi Daerah, Edisi Revisi, Jakarta : PT Raja Grafindo Persada

Mardiasmo, 2004, Otonomi dan Manajemen Keuangan Daerah, Andi, Yogyakarta

Panggabean, Edison, Hendri H, 2009, Pengaruh Pendapatan Asli Daerah terhadap Belanja

Daerah di Kabupaten Toba Samosir, Tesis Program Pascasarjana Ekonomi USU, Medan

Priyanto, Andri. 2009. Analisis Ketimpangan dan Faktor-Faktor yang Mempengaruhi

Pertumbuhan Ekonomi Provinsi Banten", tahun 2001-2008: Jurnal

Saragih, Juli Panglima. 2003. Desentralisasi Fiskal dan Keuangan Daerah dalam Otonomi.

Cetakan Pertama. Penerbit Ghalia Indonesia: Jakarta

Saragih, Junawi, Hartasi. 2010. Analisis Faktor-Faktor yang Mempengaruhi

PertumbuhanEkonomi (StudiKomperatif :KabupatenTapanuli Selatan danKabupatenLangkat) Tahun 1975-2007 : Jurnal

Waluyo,2011.Perpajakan Indonesia Edisi 10 Buku 1.Penerbit Salemba Empat,Jakarta

Zeithaml, V., Parasuraman, A., Berry, L (1990) Delevery Quality Service Balancing

Customer Perception and Expectation, USA :Free Pres Collier Macmillan Publisher

Undang-Undang Republik Indonesia Nomor 25 Tahun 1999 Tentang Perimbangan Keuangan

Antara Pemerintah Pusat Dan Daerah

Undang-Undang Republik Indonesia Nomor 32 Tahun 2004 Tentang Pemerintahan Daerah

Peraturan menteri dalam negeri Nomor 59 tahun 2007 Tentang Perubahan Atas Peraturan

Menteri Dalam Negeri Nomor 13 Tahun 2006 Tentang Pedoman Pengelolaan Keuangan Daerah

Peraturan Pemerintah Republik Indonesia Nomor 55 Tahun 2005 Tentang Dana Perimbangan

Undang-Undang No. 33 Tahun 2004 Tentang Perimbangan Keuangan antara Pemerintah Pusat dengan Daerah

Peraturan Pemerintah No. 25 Tahun 2002 Tentang Penetapan Besarnya Nilai Jual

Kena Pajak Untuk Penghitungan Pajak Bumi Dan Bangunan

Peraturan Menteri Dalam Negeri Nomor 59 Tahun 2007 Tentang Perubahan Atas

Peraturan Menteri Dalam Negeri Nomor 13 Tahun 2006 tentang Pedoman Pengelolaan Keuangan Daerah

Peraturan Pemerintah No. 55 Tahun 2005 Tentang Dana Perimbangan 
Peraturan Pemerintah No. 71 Tahun 2010 Tentang Standar Akuntansi Pemerintahan Peraturan Pemerintah No. 58 Tahun 2005 Tentang Pengelolaan Keuangan Daerah Undang- Undang Nomor 17 tahun 2003 tentang Keuangan Negara.

BPS Propinsi Sulawesi Utara

BPS Kota Manado

BAPPEDA Kota Manado 